\title{
DIAGNOSA MODEL PLAYER EXPERIENCE PADA KONTEKS DASAR USER EXPERIENCE GAME "BELAJAR HURUF ANGKA BALITA"
}

\author{
Dzuha Hening Yanuarsari ${ }^{1}$, Erisa Adyati Rahmasari ${ }^{2}$ \\ ${ }^{1,2}$ Program Studi Desain Komunikasi Visual, \\ Fakultas Ilmu Komputer, Universitas Dian Nuswantoro \\ dzuha.yanuarsari@dsn.dinus.ac.id ${ }^{1}$, erisa.adyati@dsn.dinus,ac,id ${ }^{2}$
}

\begin{abstract}
Abstrak
Generasi muda seperti anak-anak merupakan salah satu pengguna game yang mesti diperhatikan terkait dengan proses tumbuh kembang karakter anak. Seiring dengan kemunculan game digital, game edukasi merupakan salah satu Genre game dan media interaktif yang mampu memberikan metode pembelajaran yang berbeda dari yang konvensional. Game Belajar Huruf Angka Balita merupakan salah satu game digital berbasis edukasi yang bisa ditemui dan diunduh di PlayStore secara gratis dimana sampai tahun 2017 telah diunduh sebanyak seratus ribu unduhan dalam konteks game lokal. Salah satu yang diunggulkan dalam konten game ini yakni fitur yang sederhana sehingga mudah dipahami oleh pengguna game terutama anak-anak. Penelitian ini menawarkan kajian menggunakan model Player experience dalam konteks dasar User Experience dengan didukung menggunakan metode kuantitatif-kualitatif serta pengamatan. Luaran yang dihasilkan pada penelitian ini berupa hasil kajian melalui model Player experience dalam konteks pengalaman pengguna game Belajar Huruf Angka Balita yang bermanfaat sebagai rujukan pengembangan game edukasi serupa.
\end{abstract}

Kata Kunci: balita, game, media edukasi, player experience, user experience

\begin{abstract}
Young generation like children is one of the game users who must be considered related to the process of developing the character of the child. Along with the emergence of digital games, educational games is one Genre of games and interactive media that is able to provide different learning methods than the conventional. Game learning the Figures of Toddlers is one of the educational digital games that can be found and downloaded on the Play Store for free where until 2017 has been downloaded as many as one hundred thousand downloads in the context of local games. One of the main features in this game is a simple feature that is easily understood by game users, especially children. This study offers a study using the Player experience model in the basic context of User Experience with the support of using quantitative-qualitative methods as well as direct observation and interviews of children. The results produced in this study are the results of the study through the Player experience model in the context of the game user experience Learning Letter Figures Toddlers are useful as a reference for the development of similar educational games.
\end{abstract}

Keywords: toddler, game, media education, player experience, user experience 


\section{PENDAHULUAN}

Tumbuh kembang karakter dan intelegensi anak disesuaikan dengan konteks pengalaman anak dalam belajar dan kehidupan sehari-hari. Hasil penelitian menunjukan bahwa sekitar 50\% kapabilitaas kecerdasan orang dewasa telah terjadi ketika anak berumur 4 tahun, $80 \%$ telah terjadi perkembangan yang pesat tentang jaringan otak ketika anak berumur 8 tahun dan mencapai puncaknya ketika anak berumur 18 tahun, dan setelah itu walaupun dilakukan perbaikan nutrisi tidak akan berpengaruh terhadap perkembangan kognitif (Anna, 2016). Dalam konteksi ini perlu intensitas perhatian dan pendampingan orang tua dalam proses tumbuh kembang anak usia dini menuju dewasa. Eksplorasi dan implementasi dalam alat, media dan sumber belajar dan pengembangan diri anak diperlukan.

Teknologi multimedia merupakan salah satu metode pembelajaran yang muncul sebagai salah satu media edukasi baru yang mulai berkembang di masyarakat. Konsep teknologi dipadukan dengan materi pembelajaran memunculkan metode atau teknik belajar yang baru bagi anak. Dalam penelitian De Porter (2001) mengungkapkan manusia dapat menyerap suatu materi sebanyak 70\% dari apa yang dikerjakan, 50\% dari apa yang didengar dan dilihat (audio visual), dan hanya $10 \%$ dari apa yang dibaca. Multimedia menyajikan konten dalam bentuk gambar dua dimensi maupun tiga dimensi, teks interaktif, efek animasi (gambar bergerak), kombinasi warna yang menarik serta suara (audio) yang membantu anak dalam memahami materi yang disampaikan dengan lebih mudah. Multimedia dalam bentuk game menawarkan berbagai fitur berupa navigasi, interaksi dan komunikasi dimana pengguna dapat merasakan pengalaman yang cukup emosional.

Menurut Wahyudi (2011) selaku Direktur EDU Training Centre dan Ketua Bidang Peningkatan Mutu Guru dan Gerakan Literasi Ikatan Guru Indonesia (IGI) Provinsi Jawa Tengah menyebutkan bahwa Permainan video game sangat membantu anak untuk meningkatkan kecerdasan anak. Sebuah penelitian terbaru mengungkapkan bahwa video game dapat meningkatkan penalaran abstrak dan kemampuan pemecahan masalah pada anak. Game edukasi merupakan mediator dalam proses belajar dan perkembangan anak. Game edukasi adalah salah satu jenis media yang digunakan dalam memberikan pengajaran yang berupa permainan dengan tujuan untuk merangsang daya pikir dan meningkatkan konsentrasi melalui media yang unik dan menarik. Pengertian ini tentu saja mengidentifikasikan bahwa game edukasi bertujuan untuk menunjang proses belajar mengajar dengan kegiatan yang menyenangkan dan lebih kreatif (Handriyantini, 2009). Dalam era digital ini banyak sekali bermunculan game dengan berbagai genre berbasis mobile yang dapat dimainkan dimana saja. Genre game edukasi salah satunya juga banyak dikembangkan oleh pengembang game. Playstore merupakan salah satu layanan konten digital yang disediakan oleh Google Play yang meliputi berbagai aplikasi android seperti game.

Perkembangan teknologi dan maraknya game online yang muncul dengan berbagai genre merupakan fenomena yang wajib untuk diperhatikan khususnya konten isi game yang disajikan. Menurut Newman (2004:3), terdapat tiga alasan untuk meneliti game 
secara serius, yakni industri game yang semakin luas, tingkat popularitas pada game, dan game merupakan contoh bentuk dari human-interaction-computer. Selektivitas dalam memilih permainan anak merupakan salah satu yang harus diperhatikan dalam konteks peran orantua dalam mendampingi proses perkembangan anak. Pengalaman pemain dalam memainkan game (player experience) mejadi salah satu faktor yang mempengaruhi psikologi dan psikomotorik anak.

Game Belajar Huruf Angka Balita merupakan game yang bisa diunduh dari Playstore dengan Genre game edukasi yang cukup populer dengan kurang lebih seratus ribu download hingga pertengahan tahun 2017 ini dan diproduksi oleh Fazaloo Media dengan segmentasi penggunanya adalah anak balita. Game ini juga telah menduduki bintang peringkat skala 4,0 dari skala bintang tertinggi yakni 5,0 dengan jumlah spesifik totaal range yang memberikan penilaian bintang sebanyak 2.635 orang. Popularitas game ini semakin menanjak setelah media komunikasi massa yakni televisi memberitakan pembuat game berkonten edukasi ini dibuat oleh seseorang yang belum menamatkan Sekolah Dasar. Padahal konten pembelajaran yang ditonjolkan dalam game ini adalah pengetahuan dasar yang wajib dipelajari oleh anak yakni seputar pengenlan nama buah, hewan, bulan, huruf, angka, hari dan belajar menulis huruf dan angka. Pertanyaan yang menarik untuk diajukan jika kita bertanya dalam konteks diagnosa model player experience (Motivation, Meaningful Choice, Balance, Player experience dan Aesthetic) apakah sudah selaras dengan popularitas game yang banyak digemari oleh orangtua untuk didownload dan diberikan kepada ank sebagai media pembelajaran berupa game edukasi. Penelitian ini berusaha memberikan diagnosa berupa kajian dalam model kerangka player experience dan membuat rumusan gambaran pengalaman yang diperoleh oleh pengguna game setelah berinteraksi dalam game Belajar Huruf Angka Balita. Penelitian ini juga memberikan manfaat rujukan dalam menyusun perumusan konten muatan game edukasi dalam rangka pengembangan game yang serupa.

\section{METODE PENELITIAN}

\subsection{Metode Pengumpulan Data}

Metode penelitian yang digunakan dalam penelitian ini yakni metode kuantitatif kualitatif dimana mengemukakan secara rinci dan sistematis pengalaman pengguna game Belajar Huruf Angka Balita. Pengumpulan data sebagai pendukung penelitian berupa studi literatur dan observasi yang dilakukan lewat pengamatan secara langsung pengguna game yakni anak usia dini dengan kisaran range umur 0-5 tahun. Secara aspek geografis, observasi langsung dilakukan di wilayah Kota Semarang, Jawa Tengah. Pemilihan wilayah observasi langsung didasari oleh pernyataan Sugiyono (2010:11) yang menyatakan peneliti sebagai human instrument harus berinteraksi dengan sumber data sehingga harus mengenal betul sumber data dan wilayah yang ditelitinya. Pendekatan berupa teori yang dipakai dalam penelitian ini yakni model player experience yang dilandasi oleh tujuan penelitian ini yakni merumuskan pengalaman yang diperoleh oleh pengguna game Belajar Huruf Angka Balita. Metode pengumpulan data selain studi literatur yakni wawancara secara langsung terhadap anak dan narasumber yang berkecimpung dalam bidang pendidikan anak dan menyebarkan 50 
kuesioner pada responden yakni anak di Wilayah Kota Semarang, Jawa Tengah dengan disertai wawancara pada saat anak tersebut memainkan game Belajar Huruf Angka Balita.

Wawancara fenomenologi dilakukan karena target penelitian yakni anak-anak selaku pengguna game. Wawancara tersebut dipilih karena memungkinkan dan menuntut secara langsung peneliti untuk berinteraksi menggunakan gaya bahasa informal dan interaktif sehingga responden yang diwawancarai lebih terbuka (Kuswarno, 2009). Pengamatan dan pertanyaan yang diajukan dalam wawancara tersebut mengacu pada model player experience dalam konteks dasar user experience menurut Ferrara (2011) yaitu; (1) Pertanyaan yang berhubungan dengan motivasi pengguna menggunakan aplikasi game Belajar Huruf Angka Balita. (2) Pertanyaan yang berhubungan dengan struktur dan peraturan permainan yang ada dalam game Belajar Huruf Angka Balita. (3) Pertanyaan yang berhubungan dengan keseimbangan sistem dan elemen yang ada pada game Belajar Huruf Angka Balita. (4) Pertanyaan yang berhubungan dengan desain dan pengalaman yang mendukung serta pemahaman pengguna game Belajar Angka Huruf Balita. (5) Pertanyaan yang berhubungan dengan aspek desain dan estetika yang ada pada game Belajar Angka Huruf Balita.

\subsection{Model Player Experience dalam Konteks User Experience (UX)}

Salah satu kerangka kerja yang paling umum dan berguna dalam desain UX adalah User Experience (UX). Namun, model tersebut lebih sering dan khusus digunakan untuk Web. Dibutuhkan model yang berbeda untuk memahami dan merancang game. Menurut Ferrara (2011) yang mengusulkan kerangka kerja serupa yakni player experience dengan tujuan untuk membantu perancang UX membangun game yang akan lebih sukses, menarik, dan menyenangkan. Model dibagi menjadi lima bidang, yang masing-masing dibagi menjadi efek jangka pendek dan jangka panjang.

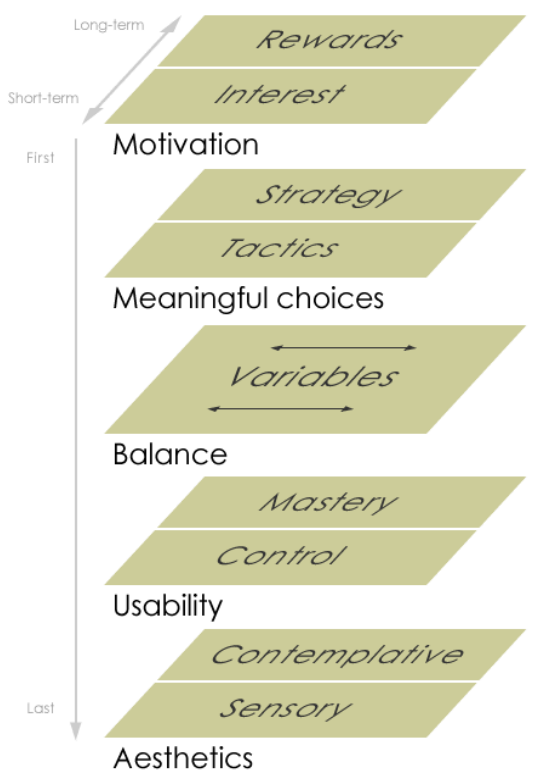

Gambar 1. Elemen dari model player experience

[Sumber : http://uxmag.com/articles/the-elements-of-player-experience] 
Elemen dari player experience meliputi 1) Motivation yakni Hal pertama yang harus dipikirkan adalah siapa pemainnya dan mengapa mereka ingin bermain game. Pesawat ini terdiri dari dua elemen utama. Elemen Pertama dalam jangka pendek, ada "ketertarikan" di muka dari pengalaman - percikan dasar yang menarik orang dan menciptakan kegembiraan dalam interaksi. Unsur motivasi kedua adalah sistem penghargaan yang menopang minat terhadap pengalaman dari waktu ke waktu. 2) Meaningful Choices yakni struktur dan peraturan permainan memungkinkan pemain untuk menggunakan pilihan yang mempengaruhi hasil kejadian. 3) Balance yakni sejauh mana elemen permainan bekerja dalam kombinasi untuk menciptakan sistem yang benar-benar menantang, namun masih menganggapnya adil dan setara. 4) Player experience yakni desain perlu mendukung pengalaman yang masuk akal, di mana para pemain memahami hal-hal yang terjadi dalam permainan dan bagaimana tindakan mereka memengaruhi mereka. 5) Aesthetics yakni mencakup banyak aspek desain estetika permainan. Dalam jangka pendek ada pengalaman sensorik langsung, yang mencakup gambar yang terdengar serta haptics umpan balik kekuatan dan pengendali permainan yang bergetar. Pilihan gaya dalam menulis dan seni mengatur nada permainan-baik lucu, serius, firasat, atau konyol. Banyak permainan juga mengandung lebih banyak elemen kontemplatif yang terbentang dalam jangka panjang, seperti narasi dengan alur cerita yang berkembang.

\section{HASIL DAN PEMBAHASAN}

\subsection{Data Game Belajar Huruf Angka Balita}

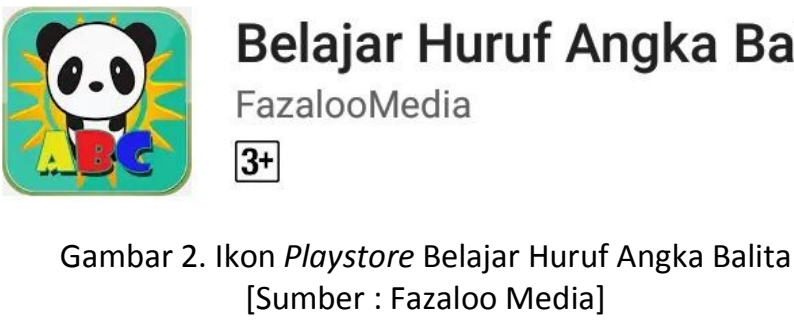

Pengembang game Belajar Huruf Angka Balita ini adalah Fazaloo Media yang dapat diunduh pada aplikasi Playstore berbasi OS Android. Game ini berGenre edukasi dengan konten pembelajaran yang digunakan untuk menunjang sarana belajar anak usia 0-5 tahun (balita) Game ini merupakan game yang digunakan untuk belajar mengenal huruf (dalam bahasa Inggris) pada anak. Platform game ini adalah mobile game dengan Genre game berupa game edukasi. Game ini mengasah kecakapan dan kepekaan anak dalam menulis huruf. Hingga awal 2017, game ini telah diunduh oleh lebih dari satu juta unduhan dan menduduki peringkat bintang skala empat dalam skala tertinggi adalah lima bintang. Pada awal permulaanya game ini menyajikan karakter pendamping untuk anak-anak yakni dalam bentuk karakter singa yang lucu sehingga tampilan game ini lebih terasa interaktif.

Game ini menyuguhkan berbagai macam fitur game pembelajaran, mulai dari mengenal buah, hewan dan hari, mengenal angka dan huruf serta menulis huruf dan 
angka. Berikut merupakan beberapa tampilan konten sederhana dari game Belajar Huruf Angka Balita dengan segmentasi anak kategori balita sebagai berikut ini :
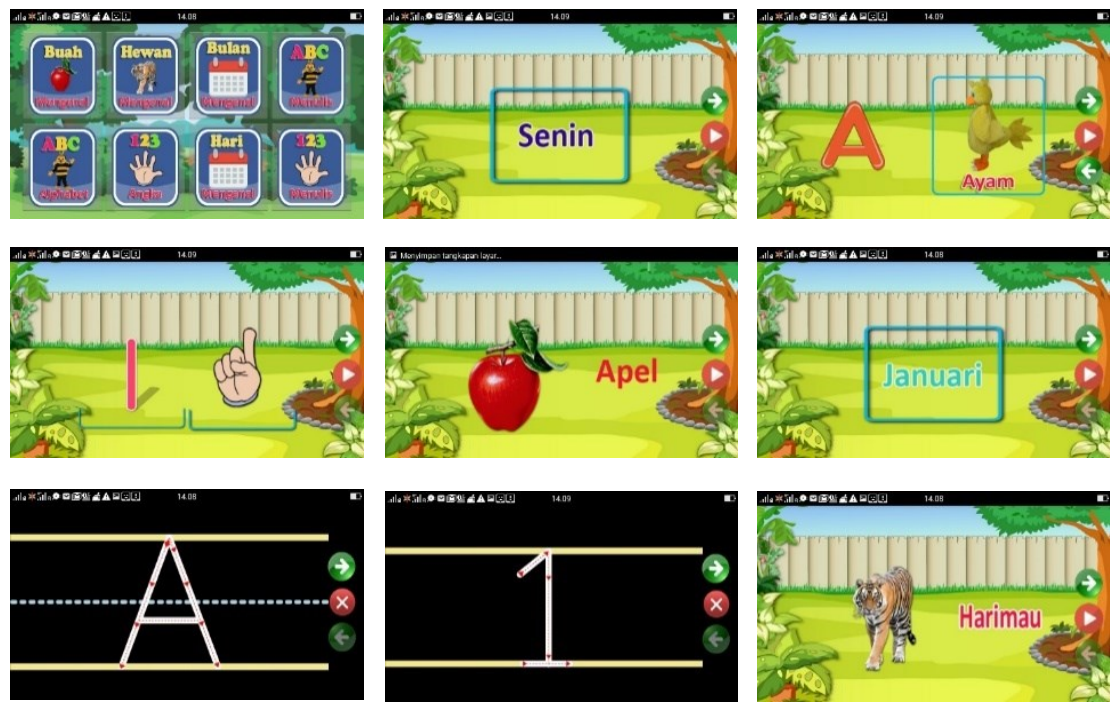

Gambar 3. Konten Game Belajar Huruf Angka Balita [Sumber : Google Playstore]

\subsection{Analisis Player Experience}

Berdasarkan proses interaksi yang dilakukan pada pengamatan awal dan wawancara yang dilakukan kepada 15 anak dengan range umur 0-5 tahun (balita) sebagai pengguna game Belajar Huruf Angka Balita dengan menggunakan pendekatan player experience yang termasuk dalam sub elemen dari konsep dasar User Experience.

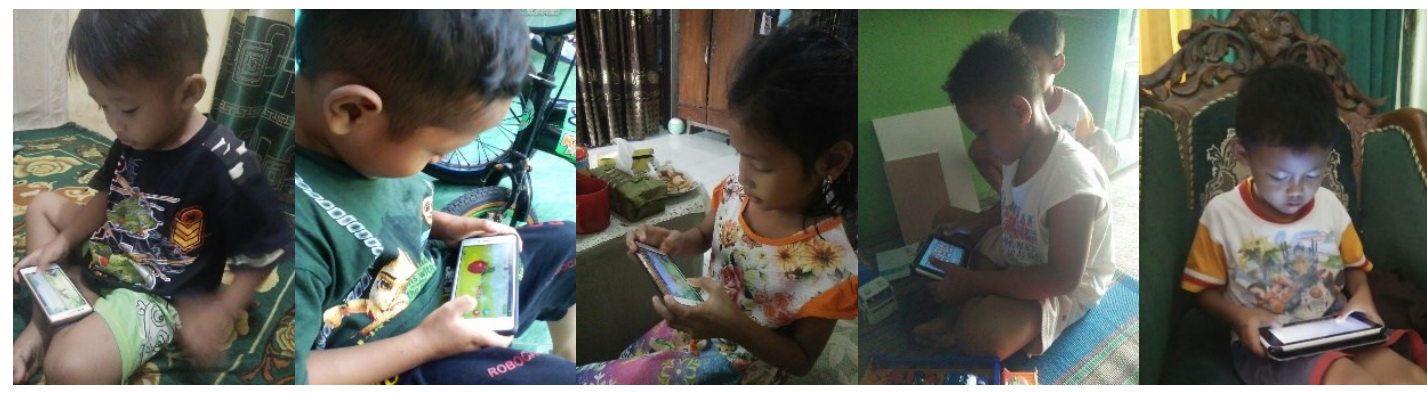

Gambar 4. Observasi pengguna game

[Sumber: Dzuha Hening Yanuarsari]

Terdapat 5 elemen dalam player experience yang dijadikan sebagai bahan analisis. Elemen tersebut dipecah menjadi 9 sub elemen yang mewakili elemen yang ada dalam Player experience berdasarkan interaksi pengguna game Belajar Huruf Angka Balita sebagai berikut: 


\section{a. Motivation}

1) Penghargaan bisa berupa hadiah atau bentuk yang akan didapat ketika pemain memenangkan permainan. (Reward Game)

2) Unsur ketertarikan yang terdapat dalam game sehingga membuat pemain tertarik untuk berinteraksi. Bisa dari pengalaman bermain atau pengetahuan yang diperoleh sebelumnya. (Interest Game)

\section{b. Meaningfull Choice}

1) Kemampuan untuk memilih strategi menang dalam permainan atau strategi bertahan dalam memainkan permainan. (Strategy Game)

2) Kemampuan untuk menggunakan teknik taktik dalam permainan untuk memenangkan game. (Tactics Game)

\section{c. Balance}

Mengacu pada elemen permainan yang disesuaikan untuk membuat pengalaman permainan yang koheren dan menyenangkan. Variabel tersebut mengacu pada konten game yang bisa meliputi keseimbangan sumber daya untuk mengatasi tantangan yang ada pada game, keseimbangan antara kesulitan dan kemudahan permainan disesuaikan dengan usia pengguna game dan sebagainya. (Variable Game)

\section{d. Usability}

1) Tingkat kemampuan pengguna dalam menguasai game yang dimainkan. Mengetahui bagaimana mereka bisa memenangkan permainan dan sebab mereka menang. (Mastery Game)

2) Tingkat pemahaman pemain untuk tindakan yang tersedia untuk mereka dan tujuan yang harus mereka tuntaskan kaitannya dengan penguasaan kontrol pada game. (Control Game)

e. Aesthetic

1) Pemahaman pengguna game dalam mengamati dan mengenali alur permainan atau cerita yang berkembang dalam game. (Contemplative Game)

2) Tingkat kepekaan pemain dalam mengindikasikan pengalaman sensorik langsung seperti gambar, suara, haptics umpan balik kekuatan. (Sensory Game)

Pada tahap penjabaran player experience menjadi beberapa unsur yang mengindikasikan tiap elemen. Unsur tersebut digunakan menjadi variabel dalam penilaian kuesioner yang dibagikan terhadap lima belas anak. Kuesioner yang dibagikan dengan metode pengisian menggunakan wawancara secara fenomenologi yakni secara langsung menggunakan bahasa yang mudah dipahami oleh pengguna game sembari berinteraksi langsung dengan game. Pemilihan responden dilakukan dengan pemilihan subjek penelitian secara random dalam konteks pengguna yang sudah pernah menggunakan game dengan pengguna game yang belum pernah sama sekali menggunakan game Belajar Huruf Angka Balita. Berikut merupakan penjabaran 
dari tabulasi data statistik yang diperoleh setelah melalui tahap pembagian kuesioner menggunakan metode wawancara secara fenomenologi sebagai berikut:

a. Motivation

1. Reward Game

\begin{tabular}{|l|c|c|c|}
\hline Variabel & \multicolumn{3}{|c|}{$\begin{array}{l}\text { Motivasi pengguna game dalam meraih penghargaan } \\
\text { dalam game berupa hadiah atau bentuk yang didapat } \\
\text { ketika pemain memenangkan permainan. }\end{array}$} \\
\hline Jawaban & Tertarik & Kurang Tertarik & Tidak Tertarik \\
\hline Frekuensi & 2 & 3 & 10 \\
\hline Prosentase & $13.3 \%$ & $20.0 \%$ & $66.7 \%$ \\
\hline
\end{tabular}

2. Interest Game

\begin{tabular}{|l|c|c|c|}
\hline Variabel & \multicolumn{3}{|l|}{$\begin{array}{l}\text { Ketertarikan pengguna game dalam berinteraksi dengan } \\
\text { game. Bisa dari pengalaman bermain atau pengetahuan } \\
\text { yang diperoleh sebelumnya. }\end{array}$} \\
\hline Jawaban & Tertarik & Kurang Tertarik & Tidak Tertarik \\
\hline Frekuensi & 12 & 2 & 1 \\
\hline Prosentase & $80.0 \%$ & $13.3 \%$ & $6.7 \%$ \\
\hline
\end{tabular}

b. Meaningfull Choice

1. Strategy Game

\begin{tabular}{|l|c|c|c|}
\hline Variabel & \multicolumn{3}{|c|}{$\begin{array}{l}\text { Kemampuan pengguna untuk memilih strategi menang } \\
\text { dalam permainan atau strategi } \\
\text { memainkan permainan. }\end{array}$} \\
\hline Jawaban & Baik & Kurang Baik & Tidak Baik \\
\hline Frekuensi & 8 & 5 & 2 \\
\hline Prosentase & $53.4 \%$ & $33.3 \%$ & $13.3 \%$ \\
\hline
\end{tabular}

\section{Tactics Game}

\begin{tabular}{|l|c|c|c|}
\hline Variabel & \multicolumn{3}{|c|}{$\begin{array}{l}\text { Kemampuan pengguna game untuk menggunakan teknik } \\
\text { taktik dalam permainan untuk memenangkan game. }\end{array}$} \\
\hline Jawaban & Banyak & Sedang & Sedikit \\
\hline Frekuensi & 3 & 5 & 7 \\
\hline Prosentase & $20.0 \%$ & $33.3 \%$ & $46,7 \%$ \\
\hline
\end{tabular}


c. Balance

Variable Game

\begin{tabular}{|l|c|c|c|}
\hline Variabel & \multicolumn{3}{|c|}{$\begin{array}{l}\text { Kemampuan pengguna dalam menguasai variabel game } \\
\text { terkait dengan keseimbangan (dalam mengatasi } \\
\text { tantangan dan mengatasi kesulitan dalam game) }\end{array}$} \\
\hline Jawaban & Mudah & Sedang & Sukar \\
\hline Frekuensi & 13 & 1 & 1 \\
\hline Prosentase & $86.6 \%$ & $6.7 \%$ & $6.7 \%$ \\
\hline
\end{tabular}

d. Usability

1. Mastery Game

\begin{tabular}{|l|c|c|c|}
\hline Variabel & \multicolumn{3}{|l|}{$\begin{array}{l}\text { Tingkat kemampuan pengguna game dalam menguasai } \\
\text { game yang dimainkan. Mengetahui bagaimana mereka } \\
\text { bisa memenangkan permainan dan sebab mereka } \\
\text { menang. }\end{array}$} \\
\hline Jawaban & Cepat & Sedang & Lambat \\
\hline Frekuensi & 12 & 2 & 1 \\
\hline Prosentase & $80.0 \%$ & $13.3 \%$ & $6.7 \%$ \\
\hline
\end{tabular}

2. Control Game

\begin{tabular}{|l|c|c|c|}
\hline Variabel & \multicolumn{3}{|c|}{$\begin{array}{l}\text { Tingkat pemahaman pemain untuk tindakan yang harus } \\
\text { dilakukan dan tujuan yang harus mereka tuntaskan } \\
\text { kaitannya dengan penguasaan kontrol pada game. }\end{array}$} \\
\hline Jawaban & Cepat & Sedang & Lambat \\
\hline Frekuensi & 10 & 3 & 2 \\
\hline Prosentase & $66.7 \%$ & $20.0 \%$ & $13.3 \%$ \\
\hline
\end{tabular}

e. Aesthetic

1. Contemplative Game

\begin{tabular}{|l|c|c|c|}
\hline Variabel & \multicolumn{3}{|l|}{$\begin{array}{l}\text { Pemahaman pengguna game dalam mengamati dan } \\
\text { mengenali alur permainan atau cerita yang berkembang } \\
\text { dalam game. }\end{array}$} \\
\hline Jawaban & Baik & Kurang Baik & Tidak Baik \\
\hline Frekuensi & 13 & 2 & 0 \\
\hline Prosentase & $86.6 \%$ & $13.3 \%$ & $0.0 \%$ \\
\hline
\end{tabular}

2. Sensory Game

\begin{tabular}{|l|c|c|c|}
\hline Variabel & \multicolumn{4}{|l|}{$\begin{array}{l}\text { Tingkat kepekaan pemain dalam mengindikasikan } \\
\text { pengalaman sensorik langsung seperti gambar, suara, } \\
\text { haptics umpan balik kekuatan. }\end{array}$} \\
\hline Jawaban & Baik & Kurang Baik & Tidak Baik \\
\hline Frekuensi & 15 & 0 & 0 \\
\hline Prosentase & $100 \%$ & $0 \%$ & $0 \%$ \\
\hline
\end{tabular}


Dari data statistik tersebut diperoleh grafik tiap elemen yang menjadi poin penilaian tingkat Player experience dalam game Belajar Huruf Angka Balita sebagai berikut:

a. Motivation

Pada elemen Motivation merupakan elemen yang mendukung pengguna untuk memiliki rasa antusias dalam memainkan game dengan fitur yang ditawarkan pada konten game. Dalam elemen tersebut terdapat dua sub elemen pembentuknya yakni elemen reward game dengan elemen interest game. Pada sub lemen reward game merupakan sub elemen yang menunjukan tingkat motivasi pengguna game dalam meraih penghargaan dalam game berupa hadiah atau bentuk yang didapat ketika pemain memenangkan permainan. pada tingkatan sub elemen ini menunjukan statistik ketertarikan pada game terkait reward game rendah yakni hanya sebesar $13.3 \%$, dimana hal ini memungkinkan terjadi karena dalam game tersebut memang tidak menyuguhkan reward pada konten game. Sedangkan sub elemen interest game yang menunjukan tingkat ketertarikan pengguna game dalam berinteraksi dengan game. Bisa dari pengalaman bermain atau pengetahuan yang diperoleh sebelumnya menunjukan hasil statistik ketertarikan yang lebih dominan yakni $80 \%$ karena dalam segi konten untuk anak usia dini sangatlah menarik karena menyuguhkan motivasi interaksi yang sederhana dan simpel.

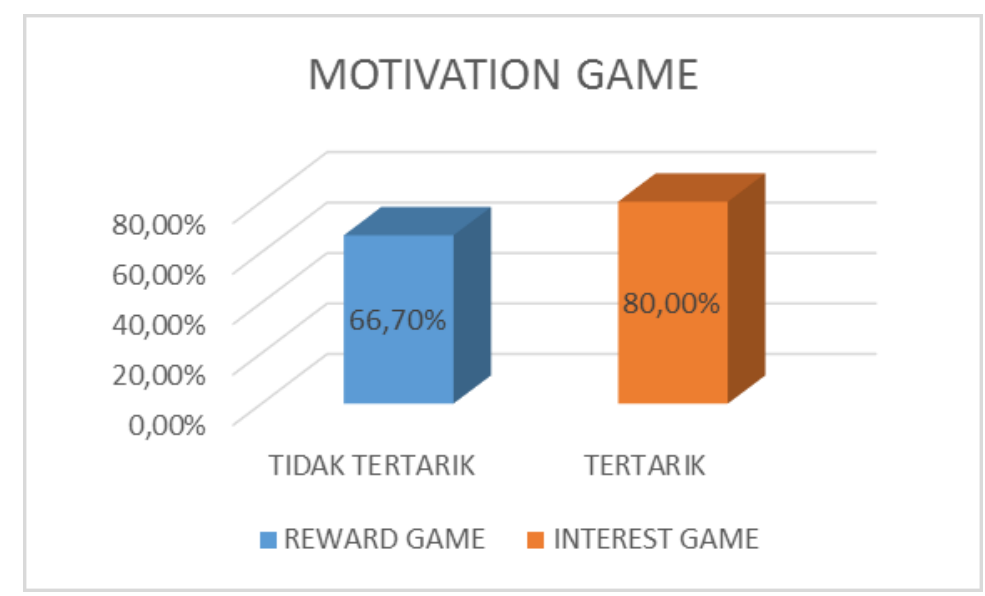

Gambar 5. Grafik Motivation

[Sumber: Dzuha Hening Yanuarsari]

\section{b. Meaningfull Choice}

Elemen meaningful choise merupakan elemen merupakan elemen dalam menentukan dan memilih strategi serta taktik dalam permainan. Dalam elemen ini memiliki dua sub elemen penyusun yakni strategy game dan tactics game. sub elemen strategy game yang merupakan elemen dalam penentuan strategi untuk memenangkan dan bertahan dalam permainan pada anak sebagai pengguna game menunjukan statistik yang baik yakni sebesar $53,4 \%$ yang bisa terjadi karena tingkat kesulitan dalam menentukan strategi dalam permainan ini tidak terlalu sulit terkait dengan konten game yang sederhana dan dirancang untuk kemudahan mencerna unsur pembelajaran dalam game yang diancang untuk anak usia dini. 


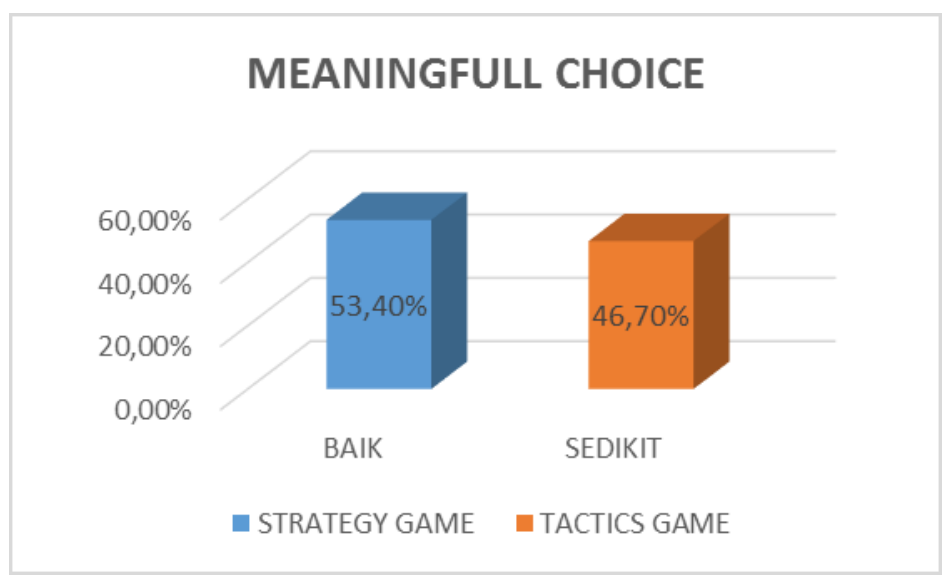

Gambar 6. Grafik Meaningfull Choice

[Sumber: Dzuha Hening Yanuarsari]

Pada sub elemen taktik game dimana menunjukan kemampuan pengguna game untuk menggunakan teknik taktik dalam permainan untuk tujuan memenangkan game menunjukan statistik yang sedikit yakni hanya sebesar $46.7 \%$. Hal ini disebabkan karena dalam konten pembelajaran edukasi untuk anak usia dini dalam game Belajar Huruf Angka Balita hanya membutuhkan stimulus ingatan yang kuat dalam mengingat bentuk-bentuk visual yang sederhana dan taktik seperti permainan yang ada dalam game action adventure sangatlah sedikit.

c. Balance

Elemen Balance dalam teori player experience merupakan elemen penyeimbang antara konten, interaksi pengguna dengan target serta karakter pengguna game. Elemen game memiliki sub elemen berupa variabel game dimana merupakan tingkat kemampuan pengguna dalam menguasai tantangan dan kesulitan dalam game.

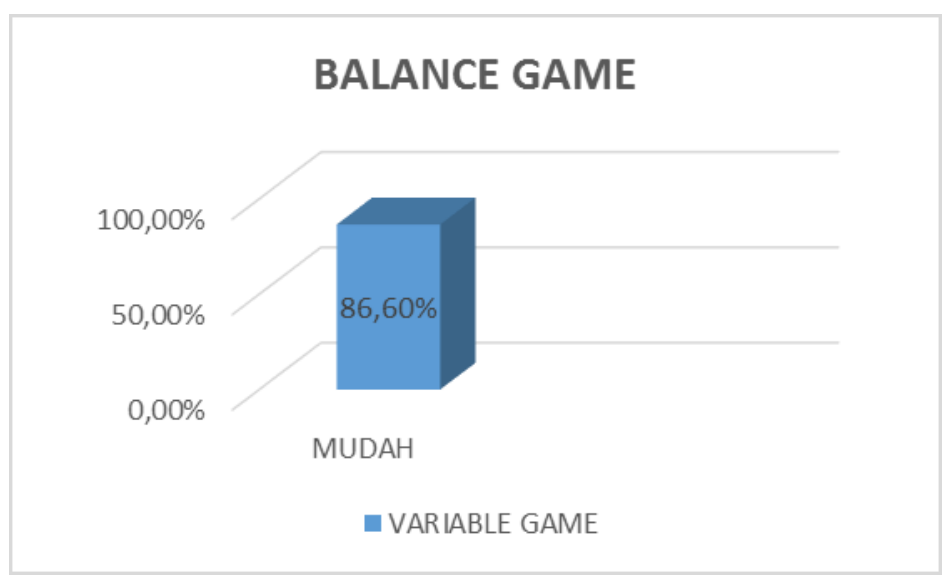

Gambar 7. Grafik Balance

[Sumber: Dzuha Hening Yanuarsari]

Pada sub elemen ini menunjukan statistik tingkat kemudahan yang signifikan yakni sebesar $86.6 \%$. Hal ini dikarenakan variabel game dalam game Belajar Huruf Angka 
Balita tidak terlalu banyak hanya terdapat delapan variabel konten pembelajaran dalam mengenal buah, hewan, bulan, menulis huruf, mengenal huruf, mengenal angka, mengenal hari dan menulis angka. Tidaklah sulit bagi anak usia dini dalam menguasai variabel dalam game tersebut. Sebenarnya variabel dalam game bukan hanya seputar tantangan dan kesulitan dalam game saja, hanya saja dalam hal ini konteks konten game yang dibuat diperuntukan untuk anak balita maka dari itu variabel dalam game yang dimasukan pada kontennya tidak terlalu banyak.

d. Usability

Elemen usability dalam game Belajar Huruf Angka balita merupakan elemen unsur kegunaan game dalam menunjang tujuan game ini yakni menggusung konten edukasi untuk anak-anak. Pada elemen ini memiliki dua sub elemen penyusun yakni mastery game dan control game. Sub elemen mastery game merupakan tingkat kemampuan pengguna game dalam menguasai game yang dimainkan yakni dalam mengetahui bagaimana mereka bisa memenangkan permainan dan sebab mereka menang.

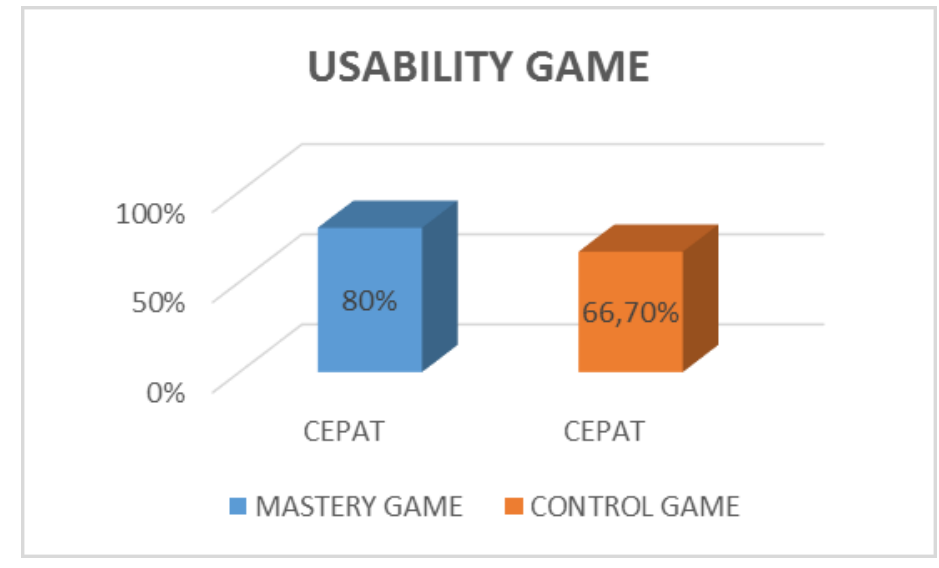

Gambar 8. Grafik Usability

[Sumber: Dzuha Hening Yanuarsari]

Tingkat statistik pada sub elemen ini menunjukan tingkat kecepatan penguasaan anak yang signifikan yakni sebesar $80 \%$. Hal ini menunjukan bahwa kemampuan anak dalam penguasaan game ini baik karena didukung oleh variabel yang terdapat pada elemen Balance. Sedangkan untuk sub elemen control game yang merepresentasikan tingkat pemahaman pemain untuk tindakan yang harus dilakukan dan tujuan yang harus pengguna game tuntaskan kaitannya dengan penguasaan pada kontrol game. Pada sub elemen ini menunjukan signifikansi kontrol pengguna pada game lebih dominan yakni dengan besaran poin $66.7 \%$. Hal ini merepresentasikan kemudahan pengguna untuk menguasai kontrol atau mengendalikan game dengan siklus yang terstruktur. 
e. Aesthetic

Elemen Aesthetic dalam game Belajar Huruf Angka Balita merupakan elemen yang mendukung segi estetis dari gambar, suara maupun alur cerita dalam game. Pada elemen ini tersusun dalam dua sub elemen yakni contemplative game dan sensory game. dalam elemen contemplative memuat tingkat pengamatan dan pemahaman pengguna dalam mengenali alur permainan yang dikembangkan.

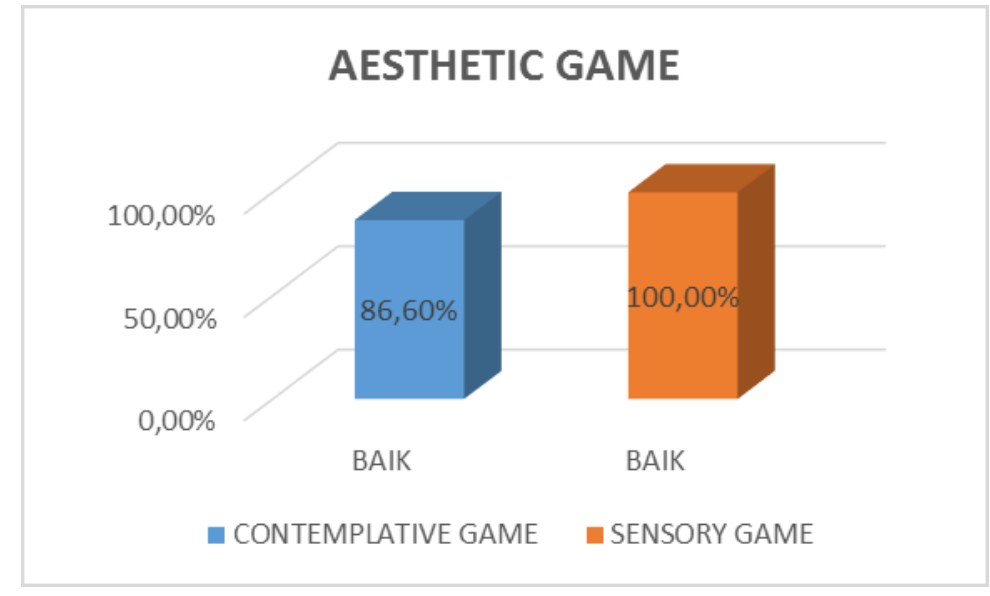

Gambar 9. Grafik Aesthetic

[Sumber: Dzuha Hening Yanuarsari]

Dalam sub elemen ini pengguna game yakni anak balita yang diteliti menunjukan daya serap pengenalan dan pengamatan alur cerita yang baik yakni sebesar $86,6 \%$. Sedangkan sensory game lebih menilai kepada kepekaan pengguna game dalam mengindikasikan pengalaman sensor pengguna dalam kepekaan gambaqr, suara, haptics, umpan balik kekuatan. Pada survey terhadap sub elemen ini menunjukkan tingkat kepekaan baik bahkan sempurna yakni sebesar $100 \%$. Hal ini menunjukan bahwa konten visual dan alur historikal dalam penyusunan alur cerita pada game sangat tersampaikan.

Berdasarkan analisis data mengenai player experience di atas, tahap berikutnya adalah penggabungan kelima elemen dalam player experienve tersebut untuk melihat tingkat statistik dan signifikansi yang dicapai penelitian pada game Belajar Huruf Angka Balita sebagai berikut: 
Tabel 1. Hasil analisis elemen player experience

[Sumber: Dzuha Hening Yanuarsari]

\begin{tabular}{|c|c|c|}
\hline No & Elemen Player Experience & Hasil \\
\hline \multirow[t]{3}{*}{1} & \multicolumn{2}{|l|}{ Motivation } \\
\hline & Reward Game & 66,7\%\% (TIDAK TERTARIK) \\
\hline & Interest Game & $80,0 \%$ (TERTARIK) \\
\hline \multirow[t]{3}{*}{2} & \multicolumn{2}{|l|}{ Meaningfull Choice } \\
\hline & Strategy Game & $53,4 \%($ BAIK) \\
\hline & Tactics Game & $46,7 \%$ (SEDIKIT) \\
\hline \multirow[t]{2}{*}{3} & \multicolumn{2}{|l|}{ Balance } \\
\hline & Variable Game & $86,6 \%$ (MUDAH) \\
\hline \multirow[t]{3}{*}{4} & \multicolumn{2}{|l|}{ Usability } \\
\hline & Mastery Game & $80,0 \%$ (CEPAT) \\
\hline & Control Game & $66,7 \%$ (CEPAT) \\
\hline \multirow[t]{3}{*}{5} & \multicolumn{2}{|l|}{ Aesthetic } \\
\hline & Contemplative Game & $86,6 \%$ (BAIK) \\
\hline & Sensory Game & $100,0 \%$ (BAIK) \\
\hline
\end{tabular}

Hasil analisis dalam tabulasi elemen Player Eaxperience di atas menunjukan tingkat signifikansi manfaat yang baik bagi anak sebagai target audience game tersebut yang ditunjukan dengan banyaknya nilai akhir yang positif. Untuk konteks elemen motivasi yang didalamnya terdapat sub elemen reward game menunjukan nilai signifikansi yang negatif. Penilaian tersebut merupakan wujud representasi dari konten game untuk reward atau hadiah dalam game memang tidak terdapat dalam game sehingga banyak anak menilai reward game yang ada dalam game tersebut negatif. Sedangkan interest game menunjukan statistik penilaian yang positif yang dapat disimplkan dari anak yang bermain dalam game tersebut dapat berinteraksi dengan baik ketika menggunakan game Belajar Huruf Angka Balita.

Elemen Meaningfull Choice dalam Game Belajar Hu'ruf Angka Balita didalamnya memuat sub elemen strategy game menunjukan nilai statistik yang baik meskipun ada pada batas ambang pertengahan. sebenarnya dalam game ini strategi yang dibutuhkan oleh anak tidak terlalu banyak, strategi dalam game edukasi bisa didapatkan anak juga sebenernya lewat pengalaman ketika sudah memainkan game belajar huruf angka balita. pada sub elemen tactics game menunjukan signifikansi statistik yang sedikit karena memang anak merasa ketika memainkan game tersebut tidak perlu membutuhkan taktik dalam teknik permainan yang banyak karena hanya dibutuhkan taktik berupa teknik mengingat bentuk-bentuk visual yang ada pada konten game tersebut.

Pada elemen Balance memiliki sub elemen variabel yang dalam konteks game sebenarnya Balance memiliki variabel yang cukup banyak. Namun disini peneliti membatasi variabel game yang akan digunakan untuk menanyai anak menggunakan bahasa wawancara fenomenologi yang mudah dimengerti dan dipahami oleh anak 
yakni pada tingkat kemampuan pengguna dalam menguasai tantangan dan kesulitan dalam game. Penilaian yang diperoleh oleh elemen ini adalah mudah. Hal tersebut ditunjukan oleh konten game yang sederhana yang tidak terlalu menyuguhkan kesulitan, hambatan dan rintangan dalam game.

Elemen Usability memiliki sub elemen yakni mastery game. Dalam Sub elemen ini memiliki penilaian anak dalam penguasaan game cenderung dominan ke cepat. Tidak adanya rintangan dan hambatan yang berarti dalam game edukasi dalam kategori pendidikan dasar ini menjadikan penguasaan materi terhadap game dcenderung ke cepat. Sedangkan sub elemen control game memiliki penilaian yang positif dan cukup signifikan. Bedasarkan wawancara secara fenomenologi langsung kepada anak, untuk anak yang belum pernah sama sekali memainkan game memiliki control game dengan kecenderungan yang lemah dibandingkan yang sudah pernah memainkan game tersebut.

Pada elemen Aesthetic memiliki sub elemen contemplative game dimana menunjukan signifikansi penilaian yang baik. hal ini ditunjukan dengan tingkat kelancaran anak dalam berinteraksi dengan game. pengenalan terhadap alur permainan dalam game belajar huruf angka balita disini tidak terlalu komplek karena dimuat dengan sederhana langsung menunjukan konten materi edukasi dari game tedrsebut. Sedangkan pada sub elemen sensory game menunjukan signifikansi penilaian dengan nilai statistik yang sempurna, terutama pada anak yangs sudah memiliki pengalaman pada gambar, bentuk dan warna benda.

\section{KESIMPULAN}

Hasil analisa terhadap konten dan isi game Belajar Huruf Angka Balita yang dibedah menggunakan teori Player Exsperience setelah melewati proses yang panjang mulai dari pembagian kuesioner dan wawancara secara fenomenologi pada anak menunjukan beberapa hasil yakni dalam penilaian secara konten game Belajar Huruf Angka Balita masih membutuhkan banyak pengembangan yakni salah satunya dalam game tersebut ditampilkan masih sangat sederhana sekali, belum ada intro maupun alur cerita kreatif yang disuguhkan didalamnya meskipun secara konten langsung pemaparan materi sudah tersampaikan kepada anak secara langsung. Perlu ditambahkan reward game dalam permainan sehingga nilai interest game juga akan lebih meningkat kaitannya dengan menumbuhkan motivasi anak untuk bermain sambil belajar menggunakan game Belajar Huruf Angka Balita. Pada kontek taktik game juga masih membutuhkan pengembangan yakni menambahkan beberapa unsur teknik permainan kaitannya juga dengan strategy game sehingga dalam permainan tersebut semakin mengasah kognitif anak dalam belajar sambil bermain pada game Belajar Huruf Angka Balita. 


\section{DAFTAR PUSTAKA}

Anna. 2016. Pentingnya Pendidikan Anak Usia Dini dalam http://www.rumahtumbuhdaycare.com/pentingnya-pendidikan-anak-usiadini/

DePorter, Bobbi, dan Mike Hernacki. (2001). Quantum Learning: Membiasakan Belajar Nyaman dan Menyenangkan. Bandung: Kaifa.

Ferrara, John. 2011. The Elements of Player experience dalam http://uxmag.com/articles/the-elements-of-player-experience

Handriyantini, Eva. (2009), Permainan Edukatif (Educational Games) Berbasis Komputer untuk Siswa Sekolah Dasar, e-Indonesia Invitiative 2009 (ell2009)

Kuswarno, Engkus. (2009). Metode Penelitian Komunikasi : Fenomenologi, Konsepsi, Pedoman dan Contoh Penelitiannya, Widya Padjajaran, Perpustakaan Pusat UII

Newman, James. 2004. Videogames. New York, USA : Routledge

Sugiyono. 2010. Metode Penelitian Pendidikan Pendekatan Kuantitatif, kualitatif, dan R\&D. Bandung: Alfabeta

Wahyudi, Johan. (2011). Ternyata Video Game Bisa Meningkatkan Kecerdasan Anak dalam http://www.kompasiana.com/johanmenulisbuku/ternyata-videogame-bisa-meningkatkan-kecerdasan-anak_5500e059a3331153725125b1, 